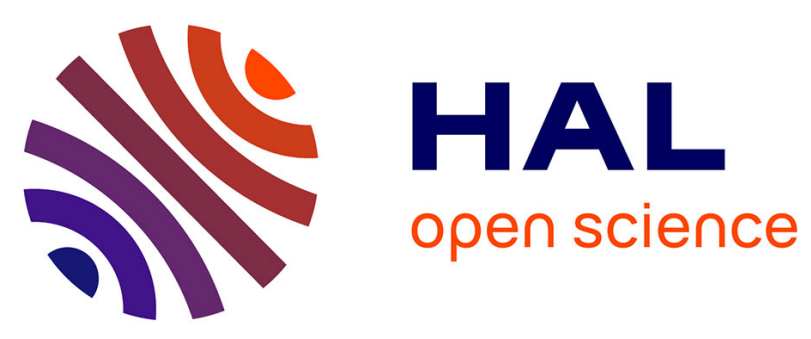

\title{
Labour market institutions
}

Bernard Gazier

\section{To cite this version:}

Bernard Gazier. Labour market institutions. Employment targeting and sectoral approaches to job creation, Oct 2013, Genève, Switzerland. hal-00976731

\section{HAL Id: hal-00976731 \\ https://hal.science/hal-00976731}

Submitted on 14 Apr 2014

HAL is a multi-disciplinary open access archive for the deposit and dissemination of scientific research documents, whether they are published or not. The documents may come from teaching and research institutions in France or abroad, or from public or private research centers.
L'archive ouverte pluridisciplinaire HAL, est destinée au dépôt et à la diffusion de documents scientifiques de niveau recherche, publiés ou non, émanant des établissements d'enseignement et de recherche français ou étrangers, des laboratoires publics ou privés. 


\section{Labour market institutions}

Bernard Gazier ${ }^{1}$

Final draft. December 2013

Contribution to the Expert Meeting on Employment targeting and sectoral approaches to job creation, ILO, Geneva, 10-11 October 2013

\section{Introduction}

In order to properly function, labour markets need a set of rules, organizations, policies and resources. Among them, unemployment insurance, wage setting rules, employment services, retraining programmes and employment protection legislation are developed to some degree in all countries, as well as a collective bargaining framework. All these elements can be considered as labour market institutions, used - and transformed - by labour market actors: firms and workers, social partners and government, this last one with a dual role: legislator and controller on one side, and a particular employer on the other. Labour markets are deeply embedded in the societies they belong to. Robert Solow summed up this point when he chose as a title for one of his books "The labor market as a social institution" (Solow 1990).

When one considers these institutions among countries, one is struck by their wide diversity and even heterogeneity. To take one example, apprenticeship is a key labour market institution in some countries where the bulk of the workers come from this training and recruiting route, while it remains marginal in others. The diversity comes from the specificity of societal contexts and history, but also from the variety of objectives pursued by each scheme and rule: e.g. efficiency and equity considerations may be combined in multiple ways. Labour markets are usually segmented in different submarkets. Some groups, benefitting from long - term and secured careers with promotional ladders, may be favoured by some institutions, while others are left aside or excluded. Another essential source of variety is the degree of implementation on the rules, depending on the size of the informal sector, on the political will and the amount of resources devoted to detecting and sanctioning noncompliance. There may be a big gap, and even an abyss between laws or signed agreements and their implementation. Last, one should take into consideration the interaction of all these institutions between each other and also with the whole social and economic sphere.

Beyond this diversity, unifying views have been elaborated by actors, experts and researchers. Several policy-oriented views emerged in the 90s, proposing different "labour market reforms" ensuring that these institutions bring or ease labour market adjustments to short

\footnotetext{
${ }^{1}$ The author gratefully acknowledges an important contribution from Kazutoshi Chatani in the elaboration of this chapter, and useful comments by Peter Auer on a previous version of the text. The usual disclaimers apply.
} 
term and long term needs. Among them, one may cite the "flexibility agenda" advocated by the OECD , the World Bank and the IMF, the "decent work" agenda promoted by the ILO, the "flexicurity" agenda developed by the European Union, and the "Transitional Labour Market" (TLM) perspective elaborated by a group of European researchers.

In this contribution, we shall not focus on the content, relevance or limits of each perspective (for a short discussion, see Auer and Gazier 2008), but we shall take stock of previous ILO work (Auer 2005 and 2007, Auer and Chatani 2011) and propose, connected to the "decent work" and TLM agendas, the concept of "protected mobility" as a synthetic priority for analyzing labour market institutions in their contribution to the creation of productive employment, in the context of the persisting difficulties created by the world crisis triggered in 2007.

The period before the crisis was characterised by a big push for labour market deregulation. The idea was that with increasing globalisation, labour markets had to adapt quickly to shifts in demand, production technologies and new markets. In general it was believed that when all other markets (e.g. goods and financial markets) became increasingly liberalized, the labour market could not remain unreformed. The crisis seemed in a first phase have led to a renewed interest in (re-) regulation, because it was believed that excessive deregulation of the financial market was the major cause of the crisis. However, very soon, reregulation of the financial sector was watered down, and the pressures for labour market reforms continued and became even stronger. In addition the idea that microeconomic factors weighing on the supply side of the economy (e.g. all institutions touching the price of labour) has again taken its dominant place, whereas during the crisis the (aggregate) demand side of the economy was seen as the lever to be pushed for resolving some of the most damaging effects of deregulation.

This facts are to be seen in all proposals and action plans for the countries still in crisis, e.g. the Southern European countries, where we can see policy packages that combine budget austerity with labour market deregulation, leading to reduced wages, social benefits and employment protection.

The benefits of regulation, and policies concerned with a high level of aggregate demand, requiring decent wages, both as stabilizing factors for the economy, are today largely forgotten. If at all, only a minimum level of LMIs is accepted by the main economic players and austerity policies dominate everywhere.

This text, while posing also some critical question in regards to excessive regulation as well, , supports the beneficial effects of labour market institutions, when they are well designed. This requires also that these labour market regulations and their reforms are not dictated top down but are bargained between the socio-economic partners.

While the text supports also ideas about the positive interaction of "smart" regulation and a more assertive demand side macroeconomic policy, it cannot develop these ideas in any length. 
The chapter is organized as follows. Section 2 discusses in some detail the meaning, justification and implications of the concept of "protected mobility". In section 3, we shall separately review four main components of labour market institutions, analyze their objectives and means in this perspective, and provide examples of interesting practices. Section 4 will be devoted to some remarks on the interplay of these institutions in the perspective of the productive transformation of an economy. Section 5 provides a short conclusion.

\section{The concept of protected mobility: from job security, employment security to labour market security}

Emerging at the beginning of this century from empirical as well as normative work done under the aegis of the ILO, the concept of "protected mobility" has been developed as a contribution to the long lasting debate on the "structural labour market reforms" advocated by international organizations such as the OECD, the IMF and the World Bank. While anybody agrees on the idea that labour markets should enhance smooth and quick adjustments to the changing conditions of our globalized world, researchers and social actors strongly diverge on the role that should be played by market flexibility: flexibility of wages, of employment contracts, of hours... A related and more consensual idea is that labour market institutions should convey flexibility as well as security: flexibility for firms and security for workers, even if this statement is simplistic ${ }^{2}$. Against this backdrop, "protected mobility" appears as a way to combine flexibility (here: mobility across jobs, firms, sectors, occupations, regions...) and security (here achieved by employment protection rules and labour market adjustment policies). But how to understand this combination and which role should it play?

We shall proceed in two steps. First we shall sum up the main arguments introducing "protected mobility" as an overarching objective for labour market institutions and reforms. Second, inspired by the "Transitional Labour Market" (TLM) perspective (see Gazier and Gautié 2011 for a recent synthesis) we shall show that in order to go further it is necessary to consider together two elements too often taken separately: transitions and positions in the labour market and around it. We shall introduce the idea of "transition capacity" from the worker's viewpoint, and show that it is critical in order to efficiently promote "protected mobility".

\footnotetext{
${ }^{2}$ Some workers may demand more flexibility (e.g. for combining paid work and family duties) and firms may demand more security (e.g. employment contracts ensuring that trained workers stay employed during a minimum period).
} 


\section{1. "Protected mobility": the core arguments}

Workers' mobility as a central labour market adjustment channel

On any market, there exist three main categories of variables that may, in a separate or in a simultaneous way, contribute to the adjustment between supply and demand: prices, quantities and qualities. In the case of the labour market, prices are wages; quantities are the number of available jobs, hours and workers; "qualities" are the skill level and competences of workers, and the skills requirements and attractivity of jobs. Wages are a variable depending on complex and multiple determinants: reflecting the productive contribution of a worker or a group of workers and / or their relative scarcity, but also reflecting hierarchical positions and career profiles, acting as an incentive and often influenced by moral, political or social norms (e.g. workers, unions and public opinion are strongly opposed to massive wage cuts $^{3}$ ). This may explain that while some wages in some sectors prove to be highly flexible and even volatile, in most sectors of the formal economy they are "sticky" i.e. they change in a smooth and organized way, for example through the translation of a wage grid as a result of a periodical wage bargaining session taking into account inflation and productivity expectations. Quantities are very often used as adjustment channels in firms and on the labour markets: modulation of working time, supplementary hours or short-time working; but also hiring and firing decisions, downsizing; these adjustments accompany the reallocation of the remaining workers inside firms; on the labour market, one may consider the size and evolution of unemployment, the case of workers taking a leave, and also the number of persons in early retirement schemes (although early retirement schemes have been widely criticized and became less relevant). Discouraged workers can also be considered as a quantity adjustment (an undesirable one) on the labour market in the case of widespread unemployment. Last, "quality" adjustments may consist in training and retraining the workforce, and in improving (or downgrading) the skill content of a given job. Of course these three categories of variables often play together and interact, each sub-variable bearing part of the needed adjustment. They can act either as complements, for example when workers' reallocation combines part-time bridging jobs and training measures and/or as substitutes, for example in the case of training that does not lead to a wage increase, which is a functional equivalent to a "hidden"wage cut, because trained and thus more productive workers are paid the same as before.

Wages are often "sticky" and difficult to adjust; most labour market adjustments are a mix of quantities (volume of hours, jobs created or destroyed) and "qualities", because, compared to destroyed jobs, new jobs appear in other plants, other firms, other sectors and / or other regions, and may be more qualified. Together with on-the-job training, this continuous process of creation and destruction of jobs is one key determinant of the productivity growth in a given country. This makes job reallocation and workers' mobility a central stake on today's labour markets and explains why, either left to deregulated processes or organized to some degree, either alone or combined with other devices such as retraining, workers mobility is at the heart of currently discussed labour market reforms proposals.

\footnotetext{
${ }^{3}$ Wage cuts have been observed in the current crisis, but they remain perceived as exceptional.
} 
From job security to employment security... and to labour market security

Following here Auer and Chatani 2011, section 5, we can start from the widely accepted and quite commonsense idea that security for workers mainly stems from holding stable jobs. This was the traditional picture offered by the first analysts of labour market segmentation (Doeringer and Piore 1971): the success criterium for a worker is, after having experienced some short-term jobs, to get a long-term work contract and become a stabilized employee in a so-called "internal labour market". This is all the more the case today, in a world where stable jobs seem to become less numerous and more difficult to obtain and keep, and where unstable, precarious jobs, seem to trap their holders into a vicious circle of marginality and poverty.

However one frequent idea popularized by analysts and policymakers is that the security ensured by firms through stable jobs is no more sufficient and that this deficiency will be durable ${ }^{4}$. Accordingly, they propose to complement (stable, firm-provided) job protection by the ability to shift from one employer to another, what implies other actors and sources, ie. employment protection.

However this shift, which has been advocated by the promoters of "flexicurity" in Europe, proved to be misleading on two important points. First, it seems to end up into a more or less virtual "employability" protection. As say Auer and Chatani 2011 (op. cit): “... the problem with selling employability as employment security is that it sells a potentiality (access to jobs) for a fact (holding a job)". Second, it neglects the key role of firms in securing their workers by organizing internal shifts from one job to another - what has been termed "employment security" in an initial and more relevant meaning. Such role has been highlighted in the case of Japanese firms developing polyvalence (ability to perform multiple tasks).

This is the reason why it is better to speak of "labour market security". Job security and employment security (in this last, restrictive sense, as provided by a single firm), cannot protect workers in increasingly flexible labour markets.. Labour market security gives additional layers of security, by organizing protected mobility, i.e. protected transitions in and around the labour market, through labour market policies and social rights. This perspective is grounded, as it has been shown by the "Transitional Labour Market" researchers, on a dynamic view on careers and workers' trajectories. Holding a stable job remains central, but as a matter of fact during the whole life course people undertake many transitions, e.g. from school and training to work, and back in the case of retraining leaves, from full-time to parttime work, from one employer to another and so on. Labour market security consists in avoiding "bad" transitions leading to durable unemployment and/or poverty, and promoting "good" transitions leading to stable and productive jobs at the end of the day. As Auer and Chatani 2011 (op. cit) conclude: "Employment security with internal adjustment flexibility and protected transitions are the two sides of labour market security".

\footnotetext{
${ }^{4}$ The question of the growing instability of the labour markets all around the world have been for many years a hotly debated topic. For a general assessment, showing that, on the long run, indicators such as job tenure remain stable and even increase, see Auer and Cazes 2003. However this statement is compatible with many observations of the growing number of unstable work contracts and the institutionalization of "precarious work", especially in the current crisis.
} 


\subsection{Transitions, positions and transitions capacities}

The key question now becomes: how to understand and combine both sides of "labour market security"? A risk would be that, for some favoured workers, firms and labour market institutions cooperate in order to organize secure careers, while for other workers the Public Employment Service will try to compensate the indefinitely renewed instability of short-term contracts. An important observation is that a complete definition of a "transition" involves not only information about the transitory period to be secured but also information about the starting point and the arrival point. A transition starts from somewhere and should lead somewhere. Taken seriously, this remark brings at least three consequences.

The first one is that policymakers intending to ensure "protected mobility" should consider not only the intrinsic characteristics of the transitions they want to foster, but also the characteristics of the "positions" they start from and they lead to. They should make sure that exist "stability poles" as safe arrival points for workers engaged into some mobility, either geographical or sectoral. The basic list of such "stability poles", beyond the public sector and private firms when they offer stable employment, is the following: the branch/sector, the trade/craft, the "territory", non-profit organizations (NPO). NPO and public employers are of course direct job providers. Branches and sectors, and trade, play as "stability poles" because for a worker with a given set of competencies it is easy and natural to contact plants and firms in the branch/sector to which belonged the firm (s)he comes from, and to apply to the same kind of work (s)he is entitled to. This leads to underline the key role played by the transferability of skills. Workers recruited in traditional "internal labour markets" sometimes develop high level competencies, but they are often specific to their firms, and then, not transferable. This may become a major source of difficulties if they are dismissed ${ }^{5}$. Last, the "territories" (regions, municipalities...) may act as a "stability pole" when proximity networks of information provide job opportunities to "local" workers. All these elements show that the fields of labour market policies and of macro-economic and productive development policies are closely intertwined.

The second consequence is that transitions and positions should be carefully considered in their gender asymmetries. During their whole career, given the current specialization of family roles, women most often face the dual constraints of care and work. This explains that they are most of the time engaged in more transitions than men (typically women take parental leaves while for men it remains an exception, or limited to a very short period), and that they often hold positions (typically part-time jobs) combining paid work and domestic work. How to make progress in gender equality and how to secure women's transitions and positions is a strategic issue.

\footnotetext{
${ }^{5}$ It is not the case with "professional labour markets", a specific version of "internal labour markets" because they recruit workers through the apprenticeship system, giving them transferable skills.
} 
The last consequence is that "protected mobility" is a subset of work and employment quality $^{6}$. Work quality is today assessed through a set on indicators comprising wages, work intensity, work interest etc. but also the security given by the employment contract, the ability to be trained, to conciliate family duties and professional tasks... all these elements are at the core of "protected mobility".

The outcome of a mobility decision is highly contextual, and depends first on the set of opportunities available to the worker. In the case of countries, sectors or regions in a situation of tight labour market, close to full employment, mobility is easier, even if the question of labour market segmentation remains relevant. We have already seen that transferable skills also are important conditions for a successful outcome. Considering the departure situation of workers and combining both dimensions of context and transferability, the analysis proposed by T. Korver and G. Schmid 2012 puts into evidence that their transition capacity may vary from strong to very weak. In a situation of rare employment opportunities and non transferable skills, some workers may become trapped into long-term unemployment, losing their employability and confidence as they remain unemployed. Some others, still employed but under the threat of being dismissed, try to keep their current job on any condition. This entails two consequences. The first is that ensuring trust in one's own initiative and developing enabling capacities is a necessary ingredient of protected mobility. The second consequence is that workers should be aware of their rights and of the institutions organizing labour market mobility. They should understand the way they function, and be able to choose the best fitting option among options available. This leads to underline the key, sine qua non role played by social dialogue in "protected mobility". in providing information about available adjustment packages..

\section{Labour market institutions and policy tools for protected mobility}

It will not be possible, within the limited format of this chapter, to examine, even quickly, the whole set of labour market institutions. They comprise wage setting institutions (bargaining practices at different levels - national, branch, firm and even plant level -, the complex set of working time regulations (normal length of a working day, holidays, supplementary hours...), training and (re)training institutions and arrangements and other active as well as passive labour market policy measures. As labour market training will be discussed in another chapter of this book, we focus our analysis on four key sets of institutions: social dialogue, Employment Protection Legislation, income protection for the Unemployed, and labour market policies including employment services which constitute a policy package relevant for protected mobility.

\footnotetext{
${ }^{6}$ On this burgeoning field, see Davoine et al 2008, Erhel and Guergoat 2011.
} 


\subsection{Social dialogue}

Social dialogue involves all the social partners, who share information, diagnoses and who bargain. It may also involve national and local government bodies (tri- or quadripartite conferences or negotiations). Social dialogue can be appraised first in the functioning of specific labour market institutions: it may be allowed, encouraged or even practiced like a routine. And it may appear, in a more transversal way, as an overarching style of governing employment relations and labour market policies ${ }^{7}$.

One may distinguish three modalities of social dialogue. The first is sharing information and diagnosis. The second is sharing decisions through collective bargaining; the third is the comanagement of some labour market institutions.

- Sharing information and diagnosis is a key and basic ingredient of social dialogue. This ensures a sense of common fate and mutual respect, ending up in a feeling of security for workers. Among the important ways of sharing information, one may cite early notice in the case of restructuring decisions involving mass dismissals, which allows workers and unions to react and take initiatives in a pondered way, opens some space for negotiated arrangements and avoids short-term interactions dominated by fear and anger. Early notice (at least six months in advance) is a frequent practice in several countries, and often stipulated by law. Other information sharing devices, are systematic and periodical meetings with social partners on the future evolution of jobs, competencies and work organization, which may prevent or better organize employment adjustment. Such meetings do not always end up into a shared diagnosis. Disagreements may persist among employers and unions, but at least partners may refer to a common basis

- The importance of constructive collective bargaining cannot be over-emphasized. It prevents labour disputes, and it leads parties in conflict to reach negotiated resolution of disputes when they arise. It helps improve working conditions, too. Some economists regard trade unions as pressure groups negotiating for undue high wages above the market clearance level, thus disturbing the function of labour markets. This view is quite biased since it neglects the positive contribution of social dialogue to productivity gains. A rich body of literature has documented the contribution of kaizen, improvement at workshop level based on social dialogue, to the rapid productivity growth realized in Japan. ILO's SCORE project replicated the model in developing countries where industrialization has been taking place. ${ }^{8}$ In addition to the benefits at the micro level, collective bargaining also contributes to a fair distribution of productivity gains, which supports the aggregate demand. Arguably, collective bargaining is more important in developing countries where production is rapidly

\footnotetext{
${ }^{7}$ In a wider perspective, Labour Market Institutions themselves can be seen as a result of social dialogue. We focus on the current functioning of LMIs.

${ }^{8}$ Sustaining Competitive and Responsible Enterprises (SCORE) project implements a practical training and infactory counselling programme that enhances the productivity, while promoting respect for workers' rights. For more details visit http://www.ilo.org/empent/Projects/score/lang--en/index.htm
} 
expanding but labour market institutions, especially labour administration, are weak. Mutual agreement between workers and employers is not a substitute for enforcement of labour regulations, but a supplement to them. In this sense, building the capacity of representatives of workers and employers in engaging in collective bargaining and forging trust among them are conducive not only to industrial peace and productivity gain but also to a broader development agenda that drives industrialization process. Nevertheless, promotion of collective bargaining often meets with challenges in many developing countries where the safeguard for fundamental workers' rights stands on a fragile ground.

\section{Building the capacity for collective bargaining: the case of Viet-Nam}

Viet Nam upholds a strategic socio-economic development objective that the nation will be a modern industrialized one by 2020 with socio-political stability (The government of Viet Nam, 2010). In this context, it has taken steps to build sound industrial relations at the national level, as well as in export-oriented sectors. The National Industrial Relations Committee (NIRC), a tripartite advisory body to the Prime Minister in the field of labour regulations and policies, was established in 2007. Since the coverage of enterprise-based collective bargaining agreements was limited, the Ministry of Labour Invalids and Social Affairs (MOLISA) implemented a pilot project to train negotiating parties and generate collective agreements in the garment and textile industry with the support of USAID and the ILO. Workers and employer representatives of the sectors negotiated employment and employment security; working and rest hours; wages, bonus and wage allowance; labour norms; workplace safety and social insurance for workers. The pilot project noted some challenges such as representation issues, negotiation skills and a lack of understanding of applicable labour regulations (ILO, 2010).

Today more collective bargaining agreements are reached with multiple employers in the same sector, but without sector-wide coverage. Under multi-employer Collective Bargaining Agreements (CBA), workers receive standardized benefits and wage packages. It is reported that this approach has seen a success in improving workplace communications between unions, workers, and employers and reducing strikes (USAID, web page). Multi-employer CBAs were reached in the garment, textile, leather, footwear and seafood sectors as of August 2011. The Vietnam Chamber of Commerce and Industry notes the importance of involving more enterprises under multi-employer CBAs (Hiep, 2011).

Social dialogue may directly foster bargained "protected mobility". In Sweden, the law governing mass redundancies (Employment Protection Act, 1974) stipulates that in order to protect the workers with long tenure, the dismissing order is "LIFO" (last in, first out) but it also stipulates that if social partners bargain and agree on a different order (typically because the firm will demand to retain younger and more skilled workers, and offers compensating resources for the older workers to be dismissed through redundancy payments and intensive re-training and placement services), their decision will dominate 
the law's provision. This enables social partners to bargain and take their own responsibility ${ }^{9}$. A recent selection of in-depth case studies collected all around the world (from Australia to Egypt, Mexico and China) showed the crucial role played by social dialogue in the management of displaced workers (ILO 2013).

- Examples of co-management of labour market institutions remain quite rare. One may cite the apprenticeship systems, co-managed by the social partners in Germany and Austria. Most often, social partners are involved in a tripartite management process with the State, this actor keeping the dominant role.

It is of course difficult to directly assess the importance and consequences of constructive social dialogue as institutionalized practices in the labour market and employment relationships. A recent attempt has been made in the case of France (Cette and al. 2013). This study is based upon a survey of French manufacturing firms collected by the Banque de France over the period $1991-2008$, including variables such as profitability and productivity, as well as variables depicting the quality of labour relations and the social climate. It considers the impact of "regulatory constraints" on the total factor productivity (TFP) in different social dialogue contexts. When social dialogue is weak and labour relations are characterized by "workforce or union opposition", the influence of "regulatory constraints" is negative on the TFP. When firms are characterized by a good social climate and the presence of branch or firm agreements, these traits offset the negative impact of "regulatory constraints" on TFP, and the interaction of the variables "regulatory constraints" and "branch or firm agreement" yields a positive significant impact on TFP.

\subsection{Employment Protection Legislation}

Employment Protection Legislation (EPL) is very often seen as a major culprit for "rigid" labour markets and is thus very often subject of reforms to allow more flexibility in labour market adjustment. It has three main components: first, the rules and constraints regarding the ability to hire and fire through open-ended work contracts; second the rules and constraints regarding short-term work contracts; and thirdt, the rules and constraints regarding mass dismissals (early notice, negotiated arrangements, severance pay...). However, even from a "pure market" point of view, EPL has strong justifications. When they dismiss workers, firms generate social costs such as income and consumption losses, unemployment, skills attrition, costs for labour market policies, etc. In this perspective, it is fair and efficient to ask firms to minimize such "negative externalities" by maintaining a fair degree of EPL.

The key question becomes of course the "optimal" level of EPL. While excessive levels of EPL may deter employment creation, there is indeed a wide variety of EPL levels and modalities with many exceptions (e.g. for small firms) all around the world (for a careful balance, see Skedinger 2011). For example, firms only hiring their workforce on short-term

\footnotetext{
${ }^{9}$ For a more systematic inquiry into the ways of setting up social dialogue in restructuring situations in the European context, see Gazier and Bruggeman (eds) 2008 and Bruggeman et al 2012.
} 
contracts will not be able to reap the gains from on-the-job training and from a continuous adaptation and progress. Firms facing relatively high levels of EPL may develop efficient tools for adapting their workforce internally and many studies show that there is a positive correlation between the level of EPL and (training) investments in the labour force.. However, in many developing countries, while formal levels of EPL seem sometimes excessive, enforcement is dramatically low and positive or negative effects of EPL can in fact not be analysed without (usually lacking) empirical evidence of enforcement. Thus, while many economists argue that EPL is a determining factor for widespread informality in the labour markets, this argument is usually assessed on legal rules only, but not on their enforcement.

\section{Employment Protection Legislation: the case of Indonesia}

Employment protection legislation is often seen as a cause of sluggish employment growth by observers since it increases the cost of hiring and firing workers. This view, however, is far too simplistic for understanding labour market dynamism, especially that of developing countries. Here we take the case of Indonesia to illustrate the point.

The Manpower Law of 2003 stipulates hiring and firing practices, severance pay, and minimum wage setting, among other labour issues in Indonesia. The effect of the Law on employment has been a subject of debate. Some observers claim that rigid labour regulations have deterred job creation because tight employee protection and high severance pay discourage investment in Indonesia and hiring workers (World Bank 2010). Rapid increase in the minimum wages was blamed for stagnant growth in job opportunities in the formal economy (ibid.).

Would reducing rigidity in employment protection legislation create more formal employment as predicted by proponents of flexible labour market? The answer for the case of Indonesia is largely no. If such a labour market reform had any effect on job creation, it would be most probably modest. This is because the causal relation between employment protection legislation and job growth is not as straightforward as is believed by observers in favour of more labour market flexibility. One must note that a variety of factors affects creation of productive employment: employment protection is merely one of such factors (ILO 2010); the weight of each factor differs depending on the country specific contexts.

In the case of Indonesia, employee protection, though it is relatively tight in the region, has turned out not to be among the most influential factors affecting creation of productive employment. An investment climate survey by the University of Indonesia ranked labour regulation as the eleventh constraints, with macroeconomic instability, transport and corruption as the top three constraints. An executive opinion survey by the World Economic Forum echoed the finding and excluded labour market rigidity from the top five impediments to business operation in Indonesia. Therefore, it is unlikely for labour market reforms of weakening employment protection legislation to have substantial employment creation effect, if critical constraints to job growth are left intact. Further, a growth diagnostic report by the Asian Development Bank, the ILO and the Islamic Development Bank identified inadequate and poor quality of infrastructure, weaknesses in governance and institutions, and unequal access to and poor quality of education as critical constraints to inclusive and sustainable growth (ADB-ILO-IDB, 2010). Fine-tuning the suspension, when the engine is in defect, would not help the car run.

\subsection{Income Protection for the Unemployed}


Social Security programs mainly replace lost income in specified situations such as illness, maternity, retirement and unemployment. Although it is essential in many countries to develop Social Security, especially "provident funds" enabling workers to accumulate pensions rights for their old age, we focus here on unemployment insurance (or unemployment benefits, hereunder UI).

UI mitigates the adverse impact of job loss and enables the unemployed to seek for suitable jobs and/or receive training without incurring high financial and psychological costs associated with joblessness. It functions not only as an important safety net in the labour market, protecting transition capacities, but also as an automatic stabilizer of fluctuation in economic activities. Given these crucial roles played by UI, most developed countries have implemented mandatory and large $\mathrm{UI}^{10}$.

Although the importance of UI is widely recognized, it is often considered as challenging to introduce it in developing countries since these countries hold a large share of workers in the informal economy and lack necessary administrative capacity. OECD-style UI is seen as unsuitable to developing countries and tailor-making UI to the country contexts is suggested (Vodopivec, 2009). Despite the challenges, many developing countries have implemented UI. Although a prevalence of informal employment does pose a significant challenge in expanding the coverage of UI, 7 to $13 \%$ of the unemployed in Argentina, Brazil, China, South Africa and Turkey were covered by UI in 2008 (ILO, 2010).

\section{Unemployment insurance: the case of Brazil}

Brazil' Federal Constitution of 1988 has established social security in the country. Protection for unemployed workers fired without a justified reason and with at least 6 months of formal work prior to dismissal was introduced by Law no. 7998 on unemployment insurance in 1990. Unemployment benefit (seguro-desemprego) replaces lost income, the amount of which is equivalent to the average monthly salary of the past three months prior to job loss but no less than the monthly minimum wage and no more than the predetermined upper ceiling. The duration of benefit is for three to five months, depending of the employment history over the past three years. Sales tax on firms funds UI in Brazil, while in most other countries contributions by workers and employers finance UI. UI supported income of 7.5 million job seekers in 2010 and mitigated the impact of the global financial crisis.

Recent studies on Brazil's UI have found positive labour market and welfare impact of the UI (Gerard and Gonzaga, 2011 and 2012). Although some observers argue that UI may discourage job losers from actively seeking jobs, little distortionary effect on the job-finding behaviour was observed in Brazil. In addition, welfare effect of extending UI programme is found to be positive and sizable. The case of Brazil indicates that a country with a large informal economy can still implement and administer UI successfully.

\subsection{Employment services}

\footnotetext{
${ }^{10}$ Space precludes here a discussion on the correct design of an UI scheme, addressing the two classical stakes of "moral hazard" and "adverse selection". For a recent and concise presentation, see Schmid 2013.
} 
An important mechanism that corrects labour market failure is employment services. They comprise career guidance, job placement services and referral to training programmes. Without such services, matching the labour demand and supply may be suboptimal. For instance, jobseekers may spend more time to find suitable jobs or may take up less suitable jobs. Similarly, employers may not be able to recruit necessary workers with right skills and lose business opportunities.

Considered in their interaction with UI, employment services may play an important role in enhancing transition capacities and ensuring a quick way back to work. It is often said that employment services are "active" while UI is "passive". In developed countries this may lead to "activation" strategies, trying to limit UI and extend employment services. However, an efficient UI is a precondition for good matches in the labour market, and should be considered, combined with employment services, as an "active" investment in the workforce (Auer et al 2005).

A central question regarding employment services is the role of public and private suppliers. Compared with most private recruitment agencies, public employment services support workers with relatively low skills and difficulties in placement. It is thus vital that public employment services help integrate low skilled workers in the labour market in order to enhance inclusiveness of growth. This could be done, either directly, or by developing partnerships with private organizations.

\section{Non-profit private employment services : the case of Cameroon}

Public employment services often face constraints including budget and service provision capacity. In this light, employment service in Cameroon is an interesting case.

Youth Employment Service (YES) Cameroon was launched as a non-profit organization in 2006 (YES Cameroon 2013). It operates in partnership with government ministries (Ministry of Youth Affairs, Ministry of Employment and Vocational Training and Ministry of External Relations), UN agencies, schools and training centres, employment services in other countries, foundations and NGOs. Activities of YES Cameroon include offering career counselling, training courses and small grant to start a business. The NPO does not provide referral services, yet its grass-root approach to support youth's insertion in the labour market has been helpful.

One of the challenges of providing employment services is outreach to jobseekers. Due to budget constraint, employment service centres are not ubiquitous in developing countries. In fact, jobseekers living in rural areas have limited physical access to employment service centres that are often located in large cities. Disseminating useful information in a costeffective manner to jobseekers remains as a challenge. An increasingly popular solution to this is the use of the Internet. Some employment services have developed online job database in which jobseekers search suitable jobs. YES Cameroon has been utilizing a popular social media to overcome this challenge. By utilizing an existing web platform, it saved the cost of developing and maintaining a website. Information on job fairs is widely disseminated thought the social media at no cost. 


\section{Protected mobility and the productive transformation of an economy}

In this last section we go back to a more global level and consider, from a dynamic point of view, the interaction of labour market institutions between themselves and with the overall economic and social productive transformation of a given country.

It would be necessary here to explicitly introduce the variety of "employment regimes" and the macroeconomic context: the diversity of situations is large all around the world., as well as the dependency of labour markets on business cycle movements. To take but one example, the world crisis triggered in 2007 has had very different outcomes in the European Unions, some countries like Spain and Greece seeing a doubling or even a tripling of their unemployment rates, while others such as Germany or Austria, keeping the same (low) unemployment rate and benefitting, among other things, from the flexibility effects of shorttime working scheme, which are traditional labour market institutions used through all recessions (Schmid 2013).

However, place constraints lead us to focus on the contribution of labour market institutions to the long-term growth process and to limit ourselves to some remarks. We shall evoke two general points and end up with an example of adaptable labour market institution.

- First, the question of the "optimal" level of mobility, often left implicit, has been discussed by ILO researchers. Auer 2007a and b showed that available statistics setting a correlation between labour productivity and the length of tenure do not deliver a single message. A wide range of tenure lengths, between 5 to 13 years seems to be compatible with the same high level of productivity. In the case of Eastern and Central Europe countries, Cazes and Nesporova 2003 identify some evidence of excessive labour market mobility: they observe for these countries "a countercyclical movement of labour turnover and a pro-cyclical movement of job tenure, in direct contrast to developments in the (western) OECD countries" (p. 138), suggesting that even in economic booms workers prefer staying in their (stable) jobs, whereas the contrary is true in the West. There many workers look for new jobs in a positive growth context, but tend to stay on their jobs in recessions. These analyses have been recently confirmed from a more theoretical point of view by a working paper of the IMF (Blanchard et al 2013) showing the limits of external labour reallocation which may induce competencies losses and hinder on-the-job training.

- A second line of remarks suggests that a homogeneous, adaptable and motivated workforce can be considered as a public good. Looking at the employment performance of countries all around the world, it has been observed that there is no systematic trade-off between quantity and quality of work (Erhel and Guergoat 2011). Competitive countries are characterized by a high quality workforce, benefitting from 
high quality work and jobs, and by the same token they generate a larger quantity of jobs. An additional observation concerns gender considerations. The productive potential of women remains enormous and should be tapped more intensively, especially in developing countries. In the long run this can only be achieved though a better sharing of domestic and labour market work, i.e. through jobs allowing a better conciliation between both spheres and tending towards equality between women and men.

- Third: in some countries, interesting steps have been made towards inclusive, legitimate, pro-active and "smart" labour market institutions. We present here an example from Austria, insisting on the pragmatic stance behind it.

\section{A case of institutional plasticity: The Work Foundations in Austria}

Dating back to 1987, the "Work Foundations" (WFs) are training, placement and reemployment units used in cases of industrial restructuring and coping with mass dismissals. Their funding is original, because they were initially created by firms as foundations (independent bodies owning a stable capital given by a big firm engaged into restructuring) and benefit from three other resources: the full access to the Public Employment Services, a co-financing contribution coming from their "clients" (the dismissed workers) who give them $50 \%$ of the interests paid on the sums yearly accumulated in their life-long severance pay account (a specific Austrian institution), and a contribution coming from the workers remaining employed in the dismissing firm and used for financing the retraining costs (in general, this contribution is around $0.5 \%$ of the wage bill).

WFs provide classical services such as competencies diagnosis, referral, (re)training and placement of the workers, with two original traits. First, they may propose quite long and even very long training programs, up to three years. Second, their "clients" are volunteers, easily recruited because workers feel confident and backed by their colleagues as well as by the whole community. These traits explain why they benefit from a good reputation, especially from potential employers.

The first WF has been set up by a big metalworking firm, Voest-Alpine, and from the start 12 firms were present. In 2011, 81 firms could benefit from this WF (Borghouts van de Pas 2011).

A first generation of enlarged versions emerged, adapted to different categories of workers and different situations: "insolvency WFs" (with a capital given by local communities), sectoral WFs and regional WFs, the last category being adapted for small and medium sized firms and for workers in short-term work contracts.

Since 2000, a second generation of enlargement appeared, with the idea that WFs should also help integrating unemployed workers by providing them the same services and guarantees. "In-placement" WFs have been created, offering intensive and long duration training sessions, especially to persons without apprenticeship records (In Austria apprenticeship is the main route from school to employment).

In 2009, there were 141 WFs offering "out-placement" services and 175 WFs offering "inplacement" services. The WFs have enrolled 10743 workers during this year, i.e. 5\% of the Austrian unemployed. The medium length of their intervention is 300 days.

An early systematic evaluation (Winter-Ebmer 2001) showed a positive outcome of such "Work Foundations". More evaluation should be necessary in order to fully assess the costs and benefits of each type of WF.

The case of the Austrian WFs shows how a legitimate and successful institution may be 
extended, diffused in other contexts, and adapted to different challenges and beneficiaries.

\section{Conclusion}

This short survey has suggested some important channels through which labour markets institutions, albeit diverse, foster "protected mobility" and contribute to a productive and inclusive growth. Most of economic theories tend to envisage a "pure" market and consider any institutions and mechanisms that hamper the smooth function of the market as "disturbances" which are desired to be removed. We showed that, properly designed and managed, labour market institutions are collective assets, protecting and enhancing not only transitions capacity but also a necessary core stability in the labour market (e.g. good and stable long-term jobs). It is the capacity of LMIs to maintain productive jobs as well as acting as a security device during necessary labour market adjustment processes that will determine their effectiveness in regard to a more assertive demand side macroeconomic policy.

In the future one may expect an even more ambitious role for these institutions, because the collective management of individual career discontinuities will call for new developments, involving more and more workers and promoting social inclusion as well as gender equality. For employment maintenance purposes new forms of internal adjustment have to be sought and for external adjustments one has to proceed from a narrow perception of unemployment insurance to a wider "employment insurance" (Schmid 2013). The task of these new or amended institutions should not only be to "make workers fit for the market", but also to "make the market fit for workers".

\section{References}

ADB, IDB and ILO (2010) Indonesia: Critical Development Constraints (Manila)

Auer Peter 2005, "Protected Mobility for Employment and Decent Work: Labour Market Security in a Globalised World”, Employment Strategy Papers 2005/1, ILO, Geneva

Auer Peter 2007a, "Security in labour markets: combining flexibility with security for decent work", Economic and Labour Market Papers 2007/12, ILO, Geneva

Auer Peter 2007b, "In search of optimal labour market institutions", in H. Joergensen and P.K. Madsen (eds), Flexicurity and Beyond: Finding a New Agenda for the European Social Model, DJOF publishing, Copenhagen, p. 67 - 98

Auer Peter 2010, "What's in a name: the rise (and fall) of flexicurity", The Journal of Industrial Relations, 52(3), p. 371 - 386 
Auer Peter 2013, From security beyond employment to security in employment, paper presented to the $27^{\text {th }}$ AIRAANZ conference "Work, Employment and Employment Relations in an Uneven Patchwork World", 6 - 8 February, Fremantle

Auer Peter and Cazes Sandrine 2003, Employment stability in an age of flexibility, ILO, Geneva

Auer Peter, Efendioglu Umit and Leschke Janine 2005, Active Labour Market Policies Around the World: Coping with the Consequences of Globalization, ILO, Geneva

Auer Peter and Gazier Bernard 2007, L'introuvable sécurité de l'emploi, Flammarion, Collection « Champs », Paris

Auer Peter and Gazier Bernard 2008, «Flexicurity as a Policy Agenda », CESifo DICE Report $4-2008$, pp. 3 - 8

Auer Peter and Chatani Kazutoshi 2011, "Flexicurity : Still going strong or a victim of the crisis?", in K. Townsend and A. Wilkinson (eds), A Research Handbook on Work and Employment Relations, Edward Elgar, Cheltenham

Berg Janine and Kucera Daniel (eds) 2008, In Defense of Labour Market Institutions: Cultivating Justice in Developing World, Palgrave MacMillan

Blanchard Olivier, Jaumotte Florence and Loungani Prakash 2013, « Labor Market Policies ans IMF Advice in Advanced Economies During the Great Recession », IMF Staff Discussion Note, March SDN/13/02

Borghouts - van de Pas Irmgard 2011, Securing job-to-job transitions in the labour market : a comparative study of employment security systems in European countries, Thesis, University of Tilburg

Bruggeman Frédéric, Gazier Bernard and Dominique Paucard 2012, «Affronter les restructurations d'entreprise en Europe. Propositions pour une démarche unifiée », Revue de l'IRES n ${ }^{\circ} 72$, pp $29-64$

Cazes Sandrine and Nesporova Alena 2003, Labour markets in transition. Balancing flexibility and security in Central and Eastern Europe, ILO, Geneva

Cette Gilbert, Dromel Nicolas, Lecat Rémy and Anne-Charlotte Paret 2013, "Labour Relations Quality and Productivity: an Empirical Analysis on French Firms", Review of Economics and Institutions, Vol. 4, $\mathrm{n}^{\circ} 2$, Spring, article 2

Davoine Lucie, Erhel Christine, Guergoat-Larivière Mathilde 2008, "Monitoring quality in work: European Employment Strategy indicators and beyond", International Labour Review, No.147, 2-3, pp.163-198

Doeringer Peter and Piore Michael 1971, Internal Labor Markets and Manpower Analysis, Heath Lexington Books 
Erhel C., Guergoat-Larivière M. 2011, "Job quality: A comparative perspective on the basis of EU indicators”, WISO - Wirtschafts- und Sozialpolitische Zeitschrift, Vol. 34, June, pp.143 $-159$

Gazier Bernard and Bruggeman Frédéric (eds) 2008, Restructuring Work and Employment in Europe. Managing change in an Era of Globalization, Eward Elgar, Cheltenham

Gazier Bernard and Gautié Jérôme 2011 "The Transitional Labour Markets Approach: Theory, History and Future Research Agenda", Journal of Social and Economic Policy: Vol. 14: Iss. 1, Article 6

Gerard, François and Gonzaga Gustavo 2011, "Unemployment insurance in developing countries: The case of Brazil" Textos para discussão 593, Department of Economics PUC-Rio (Brazil).

Gerard François and Gonzaga Gustavo 2012, Social insurance under imperfect monitoring: Labour market and welfare impacts of the Brazilian UI program, presented at the Latin American and Caribbean Economic Association (LACEA) and Latin American Meeting of the Econometric Society (LAMES) 2012 Annual Meetings, Lima, Peru.

Government of Viet Nam (2011) “Vietnam's Socio-Economic Development Strategy for the period of 2011-2020", in Vietnam Institute of economics, Vietnam's socio-economic development, No. 67, September 2011 (Hanoi)

Hiep, Luu (2011, August 05) Collective employment agreement: Universal application needed, Vietnam Chamber of Commerce and Industry News, retrieved 20 September 2013, from http://vccinews.com/news_detail.asp?news_id=23852.

ILO (2010) Labour and social trends in Viet Nam 2009/10 (Hanoi).

ILO (2010) Employment and social protection policies from crisis to recovery and beyond: A review of experience (Geneva)

ILO (2011) Labour and social trends in Indonesia 2010: Translating economic growth into employment creation (Jakarta)

ILO 2013, Responding to worker displacement: A collection of case studies, Geneva

ILO 2013, (website) Global extension of social security (http://www.social-protection.org) [accessed on 23 September 2013]

LPEM-FEUI (2007) Investment climate monitoring: Round IV (Institute for Economic and Social Research, University of Indonesia, Jakarta)

Korver Tom and Schmid Günther 2012, "Enhancing Transition Capacities and Sustainable Transitions" in De Munck J., Didry C., Ferreras I. and Jobert A. (eds) (2012), A New Path toward Democratic Deliberation: Social and Civil Dialogue in Europe, London and Brussels, Peter Lang, pp. 26-57 
Marsden David 1999, A Theory of Employment Systems, Oxford U. Press

Schmid Günther (ed.) 1994, Labor Market Institutions in Europe. A Socio-economic Evaluation, M. E. Sharpe

Schmid Günther 2013 forthcoming, "Sharing Risks of Labour Markets Transitions: Towards a System of Employment Insurance", British Journal of Industrial Relations

Schmid Günther and Gazier Bernard (eds) 2002, The Dynamics of Full Employment. Social Integration through Transitiona Labour Markets, Edward Elgar, Cheltenham

Skedinger Peter 2010, Employment Protection Legislation. Evolution, Effects, Winners and Losers, Eward Elgar, Cheltenham

Solow Robert 1990, The Labor Market as a Social Institution, Basil Blackwell, Oxford

USAID, "Vietnam develops a new way to prevent labor disputes: Technical assistance and experiences from the United States promote first multi-employer collective bargaining agreement" [web page] retrieved 21 September 2013, from http://vietnam.usaid.gov/vietnamdevelops-new-way-prevent-labor-disputes-technical-assistance-and-experiences-united-statesp.

Vodopivec, Milan (2009) Introducing unemployment insurance to developing countries, SP Discussion Paper No. 907 (OECD, Paris)

Winter - Ebmer Rudolf 2001, "Evaluating an Innovative Redundancy-Retraining Project: the Austrian Steel Foundation”, IZA Discussion Paper, n 277

World Bank (2010) Indonesia jobs report: Toward better job and security for all (Jakarta)

World Economic Forum (2009) The global competitiveness report 2009-2010 (Geneva)

YES Cameroon [web site] http://www.yescameroon.org/en/ [accessed on 29 September 2013] Facebook page of YES Cameroon https://www.facebook.com/pages/Youth-EmploymentService-YES-Cameroon/142655939131811 [accessed on 29 September 2013] 